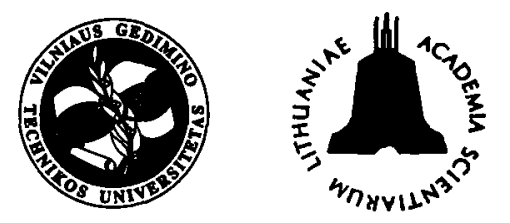

ISSN 1392-3730

JOURNAL OF CIVIL ENGINEERING AND MANAGEMENT

http:/www.vtu.lt/english/editions

2003, Vol IX, No 3, 208-213

\title{
MODERN WAYS OF DESIGNING ROADS THROUGH URBAN AREAS
}

\author{
Jiří Čarský1, Aida Mað̌erinskienè $\dot{e}^{2}$ \\ ${ }^{1}$ Faculty of Transportation Science, Czech Technical University in Prague, \\ Konviktská 20,CZ-11000 Praha 1, Czech Republic.E-mail: carsky@fd.cvut.cz \\ ${ }^{2}$ Dept of Urban Engineering, Vilnius Gediminas Technical University, \\ Saulètekio al. 11, LT-2040 Vilnius, Lithuania \\ E-mail: aida.macerinskiene@ap.vtu.lt
}

Received 12 Dec 2002; accepted 23 May 2003

\begin{abstract}
An important part of forming traffic plans is through designing better traffic conducting. The through roads in urban areas are places of great traffic importance and the concentration of traffic can create serious problems. Solving of this problem significantly influences the future position and functions of current through roads in urban road networks as well as creating the possibilities of new traffic and technical organisation. The purpose of the process of the formation of modern and traffic easing on through roads is to reach better safety levels for all road users, improving pedestrian and cyclist conditions, optimising the used traffic spaces, improving the aesthetic standards of the through roads and slowing down the environmental impact of air pollution and traffic noise. For this purpose the new methodology defines a large number of project elements and specifies the possibilities of its use. It should support new ways of thinking in the designing of through roads and traffic easing, because the implementation of modern European trends is necessary in Lithuania.

Firstly it is necessary to choose the optimal road speed and maximum speed limits. The suitable speed limit will depend on the traffic volume, on the number of pedestrians and cyclists and on the surroundings characteristics. Traffic easing elements on through roads generally do not cause a decline of capacity, but under specific conditions it can increase them. The use of particular elements and disposals depends on the place, eg where different elements are recommended to be placed before entry into any town/village, on the town/village's entry or in the use of through roads inside a town/ village. Among the most used project elements in traffic easing on through roads, belong changes for the better modification of cross-sections and parking lanes, the implementation of middle traffic islands, local bottlenecks of traffic lanes, modification of crossings for pedestrians and the use of small roundabouts and finally under limited conditions and the use of traffic humps.
\end{abstract}

Keywords: through road, speed limit, traffic easing, pedestrian crossing, traffic lane, parking lane, middle traffic island.

\section{Introduction}

Mobility is essential to the livelihood of cities. However, traffic saturation levels reached due to the dominance of private cars are impairing the efficient functioning of many cities by reducing accessibility and damaging the environment in the long term [1]. Developments of lifestyle changes have encouraged the separation of homes and economic activities. This has resulted in a great increase in traffic flow and a dramatic shift in modes of transport, ie away from walking, cycling and public transport to the private car $[2,3]$.

In Lithuania ordinary bypass construction practices show that bypasses exists at a great distance from distant towns, are of poor quality and run to where buildings stand and then the roads become another street. This can be seen in the northern Vilnius transport passage
(Nemenčiné-Vievis) and the southern (Paneriai-Naujoji Vilnia) bypasses. These roadways have poor loading areas. Positive influences are quite weak between Vilnius and other town traffic systems [4].

An important part of traffic plan formation is through traffic conducting. The through roads in urban areas are places of great importance and for this reason the concentration of traffic can cause serious problems. Solving this task significantly influences the future position and functions of current through roads in urban road networks, as well as creating possibilities for new traffic and technical organisation. The purpose of the process for modern formation and traffic easing of through roads is to reach better safety levels for all road users, the improvement of pedestrian and cyclist movement conditions, optimising used communication space, the improvement of aesthetic standards of through roads and to slow down 
the environmental impact of air pollution and road traffic noise. For this purpose the new methodology defines a large number of project elements and specifies the possibilities of their use. It should support new ways of thinking in designing through roads and traffic easing, because the implementation of modern European trends has become necessary in Lithuania [5].

Among the main insufficiencies of through roads are the same sized cross-sections widths outside towns or villages that should enable rapid and fluent vehicle passing [6]. Traffic lane widths are overdesigned to the detriment of non-motorised traffic participants and also missing are constructional elements that make pedestrian crossing easier. Roads with narrow sidewalks and without cycling communication areas create barriers to easy traffic movement.

The effects of the present layout are all the unnecessarily high in number accident frequencies, the high traffic noise levels and the very small green areas, in proportion to other areas. Passing cars and parked cars prevail in the overall image of these communication systems today.

\section{General requirements and criteria for re-designing through roads}

Among the basic standards required for correct proposals, are the maximisation of safety levels and improvement of conditions for the movement of all traffic participants, those using the activities of communication surroundings, the economy of the environment and the aesthetical quality of new proposal standards [7-9].

The first step that is necessary before any new through road design or existing through road is re-designed is the selection of an optimal road speed (the maximum speed limit). The suitable speed limit will depend on the traffic volume, on the number of pedestrians and cyclists and on the characteristics of the surrounding town or countryside and the residential area or industrial area.

The through road should be designed by using the maximum speed limit along the whole road. If the road is too over designed it causes drivers to not respect the official speed limit. Dividing a road into relatively homogenous parts according to the local road characteristics and traffic sign locations with marked speed limit (different for every part of road) is more acceptable than is leaving the road without any speed limit markings at all. Experience shows that drivers have a tendency to respect more frequently marked speed limit areas on local traffic signs than when using the general speed limits that are valid for different types of roads.

It is also very important to notice, where the traffic signs marking the beginning/end of a town/village are situated. A typical feature in the Czech Republic is to locate these traffic signs outside the real village or town beginning. When drivers do not see any buildings directly behind this traffic sign, they lose the motivation to respect this traffic sign and to slow down in time.

The importance of communication capacity standards rises when there is a higher traffic volume; and often the opposite argument for the realisation of traffic easing elements is fear of their negative impact on the capacity (above all with traffic and parking lane width reduction). Especially in towns, where the maximum traffic volume can come through at an average speed of $30 \mathrm{~km} / \mathrm{h}$, traffic easing on through roads can also increase their capacity. The safety areas on pedestrian crossings have a favourable influence on the communication capacity; this enables pedestrians to cross in a shorter time between vehicles $[9,10]$.

\section{Traffic easing elements depending on the area of use}

Before entry to any town/village there were:

- Gradual traffic speed reductions by use of traffic signs.

- A local bottleneck before the village.

- Transversal strips on the carriageway with different colours and pavements.

On town/village entry there could be:

- Use of a central traffic island (for divergence of traffic lane destined into town or village - Fig 1).

- Physical bottleneck of traffic.

- Local narrowing of communication (best is by means of a green area, e.g. a gate).

- Use of a small roundabout.

- Changes of communication pavements.

Inside town/village there could be:

- Traffic lane widths or general communication crosssection arrangements (Fig 2).

- Pedestrian crossings and crossroads arrangement (Fig 3).

- Space revival by means of green areas, equipment and communication lighting elements

\section{Optimising the traffic lane elements}

The narrowing of traffic lane (Fig 4) widths increases a drivers' tendency to drive a car more slowly, therefore traffic lane widths should be only as narrow as is necessary. Among the basic standards influencing the minimal usable width of traffic lanes belong buses and lorry traffic volumes, the functional class of communication, the functional use of communication surroundings and speed limits (this is generally $50 \mathrm{~km} / \mathrm{h}$, but can be $30 \mathrm{~km} / \mathrm{h}$ locally). Traffic lane widths in towns/villages and outside towns/villages are not related and do not need to be similar. The most frequent case is the change of traffic lane widths in towns/villages from 3,5 $\mathrm{m}$ to $3,0 \mathrm{~m}$.

When it is not possible to narrow the existing road width, a significant colour or different kind of material is used on the road edge and surface so as to create the visual illusion of a narrower lane. 

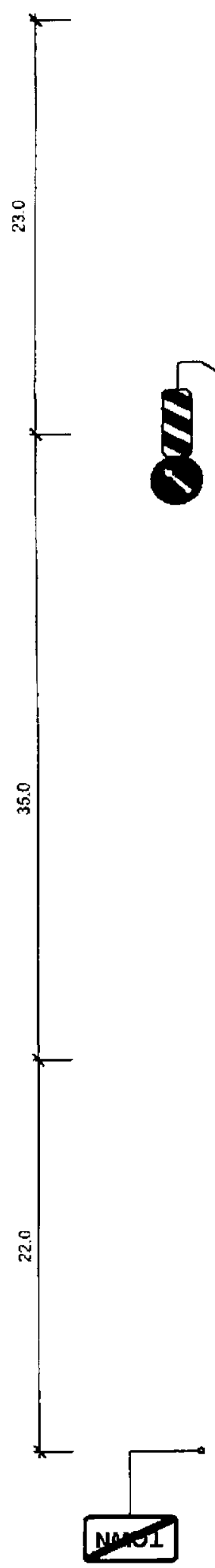

Fig 1. Traffic easing elements depending on the area of use (before entry to a residential area)

The basic and until recently most commonly used drain edge width is $0,5 \mathrm{~m}$. This width can be given for the disposal of alternative elements as far as gullies are located outside the carriageway or under kerbs (Fig 5).

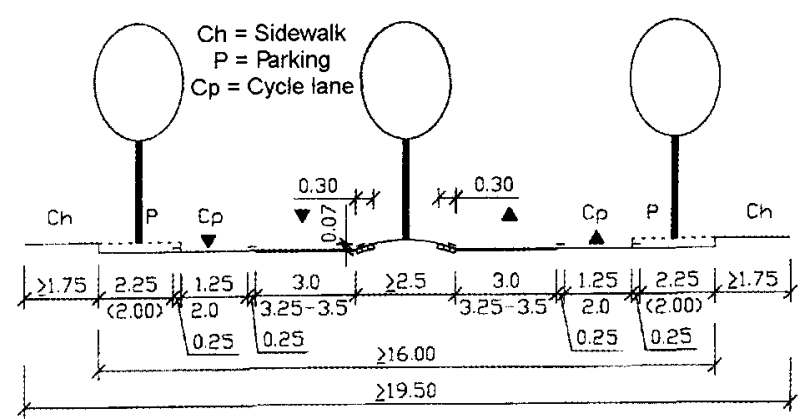

Fig 2. Traffic line with a general cross-section arrangement

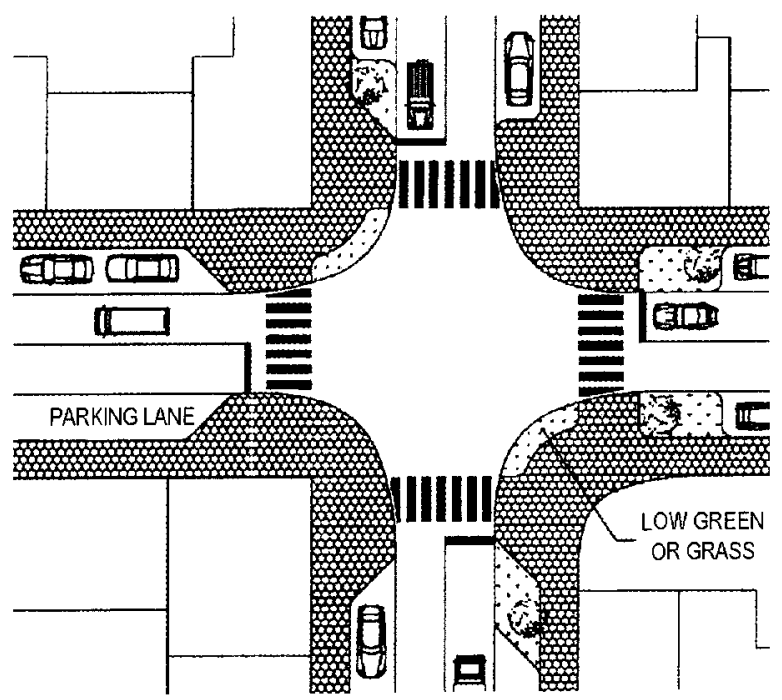

Fig 3. Scheme of Pedestrian crossings and crossroad arrangements inside a pedestrian area

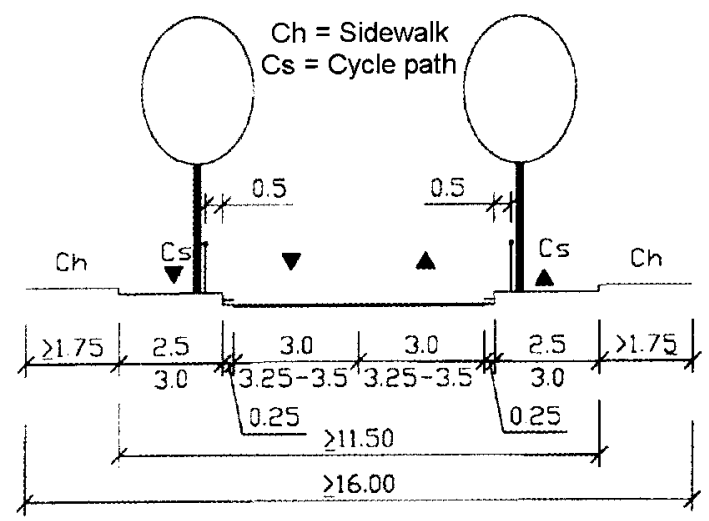

Fig 4. Traffic line crossroads

When there is no other possibility to park outside the through road, parking lanes for parking in the same traffic direction is the best solution to finding enough parking places. The parking lanes should be interrupted at periodic intervals (ie after every 3-6 car parking places) by grass or a sidewalk cap (Fig 3). 


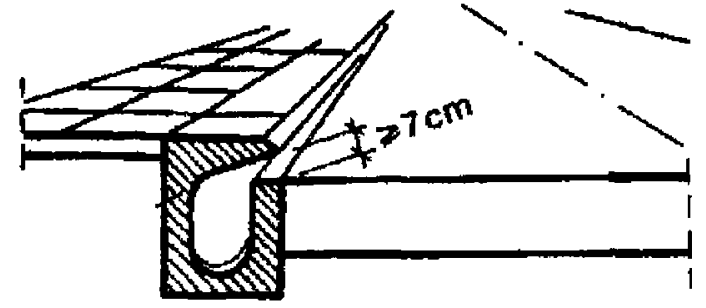

Fig 5. Fragment of the usage of a drain edge with under kerbs

Middle traffic islands can be divided according to:

- Purpose: islands for speed reduction in front of the town (Fig 6), for safer pedestrian crossings (Fig 7) and for safer left turning (Fig 8).
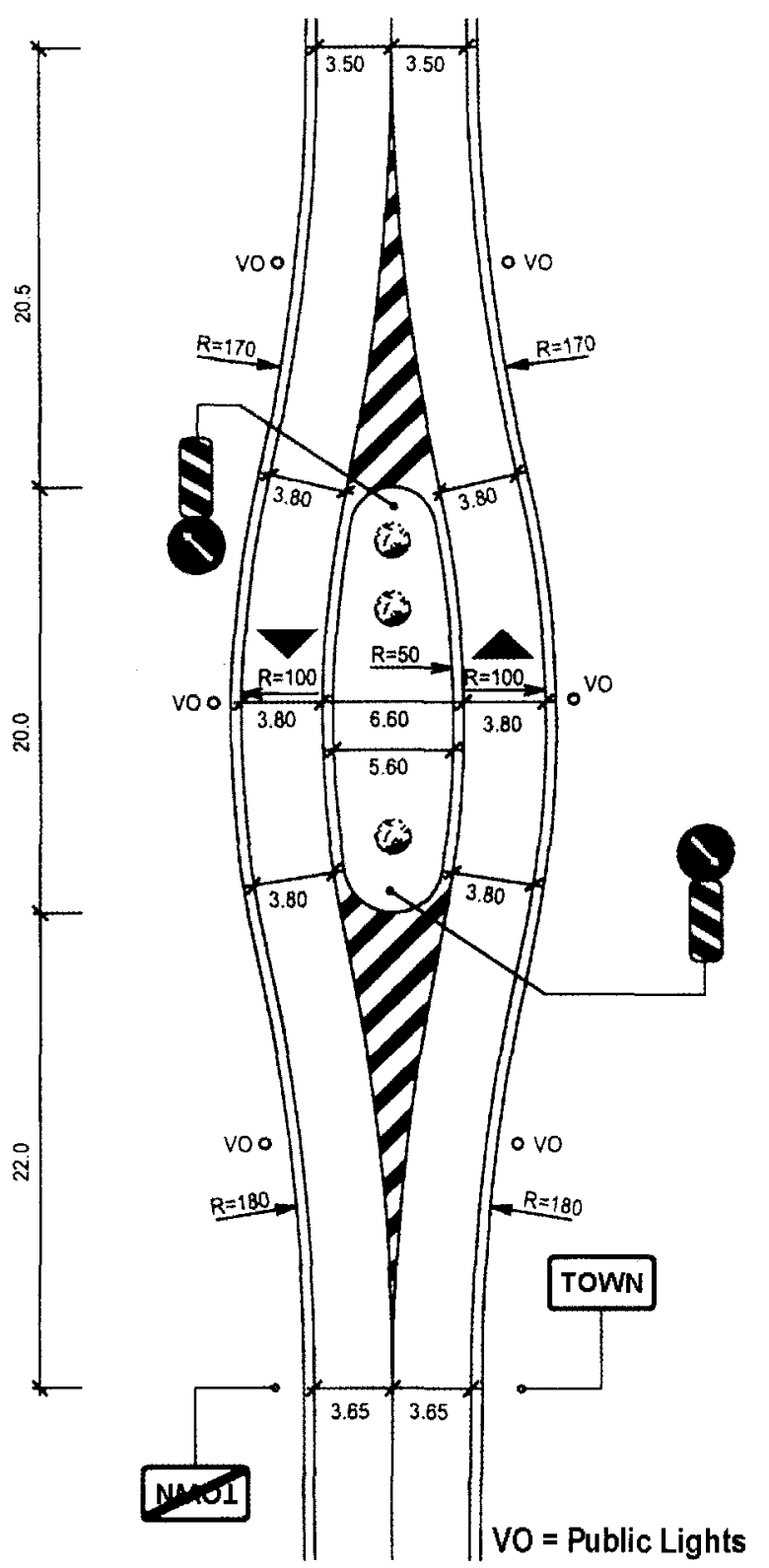

Fig 6. The scheme of middle traffic island usage
- Layout: without significant changes to the traffic lane axis (Fig 6) or with significant modification of the axis (Fig 1).

- Construction: physical traffic island, ghost island marked by another kind of pavement or marked only by road marking shades.

Central traffic islands on entries into towns/villages lessen the carrying over of high speeds from the outside to the inside of towns/villages and therefore their use is increasing quickly. It is suitable for entries into villages and small towns especially. In order that drivers who pass the speed limit do not drive faster than the speed limit in towns/villages, the proposal must satisfy the following requirements:

- Movement of traffic lane axis about $2 / 3$ of traffic lane width minimally (Fig 1).

- Good visibility of the island (this can be extended by means of a green area).

- Street lighting of the island during the reduction of visibility.

- Use of vertical traffic signs (Fig 1 and 8).

Middle traffic islands for safer pedestrian crossings improve pedestrians' safety and increase the capacity for crossing. Their principal advantage is a division of the crossing into 2 phases of traffic regulating. The creation of a protected area for pedestrians (Fig 8), the reduction of physical stress on pedestrians, deceleration and canalisation of traffic flow and support overtaking prohibition on crossings are other important principals. These islands can be applied one after another even several times with a minimal distance of $100 \mathrm{~m}$ approximately. Minimal width of these islands is $1,75 \mathrm{~m}$; nevertheless a width of $2,00 \mathrm{~m}$ is for pedestrian safety. The length of an island is designed between 6-8 m.

Middle traffic islands for safer left turning (Fig 9) eliminate waiting lane's abuse by overtaking and reduce the risk of accidents from behind. A positive contribution as well as the reduction of traffic in the area and a reduction of collision points is seen in the use of these islands.
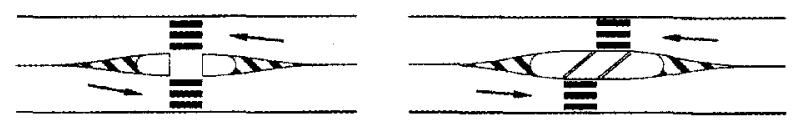

Fig 7. Safer pedestrian middle traffic islands

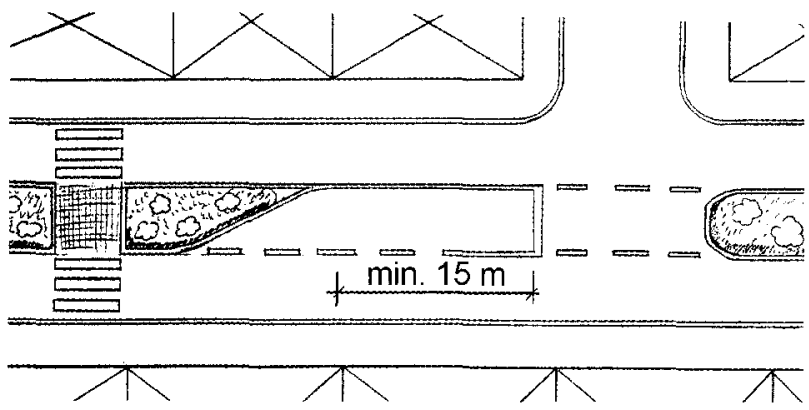

Fig 8. Safer left turning at middle traffic islands 
A strip of $20-100 \mathrm{~m}$ long is suitable in places where a left turn is forbidden or undesirable. The strip usually consists of consolidated (Fig 10) and unconsolidated grass parts. The length and frequency of these consolidated parts in the middle strip directly influences the possibility to overtake another vehicle (Fig 2). The advised minimal width of a central middle traffic strip is $2,5 \mathrm{~m}$. From the point of view of capacity it is possible to use it without problems with the traffic volume of up to 900 cars/hour (in both directions).

Sidewalk capes can be situated before and behind the pedestrian crossing to reduce its length (Fig 3) or beside the tram/bus stops (Fig 11) to make it safer to get on and off from trams/buses. Stop capes are one of public transport advancing forms, because they increase the safety and comfort of waiting passengers and accelerate the buses or trams stopping time.

Further outstanding advantages of sidewalk capes are:

- Shortening of the crossing length and time of pedestrians passing in collision areas.

- $\quad$ Physical parking prevention (especially in crossroads areas).

- Improvement of optical contact between driver and pedestrian.

- A chance to use this area for other functions (stands for bicycles, parking meters).

- Reduction of optical predominance of wide traffic.

- Traffic signs and streetlights located more closely to traffic lanes.

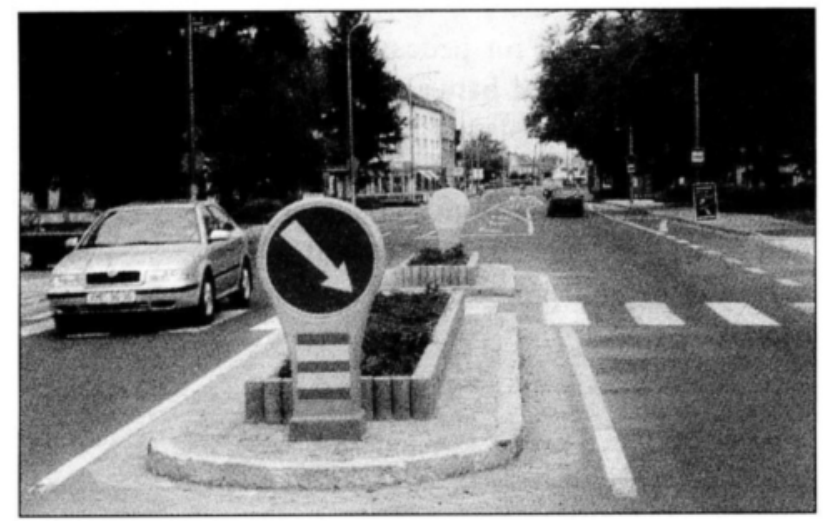

Fig 9. The traffic island for safer left turning

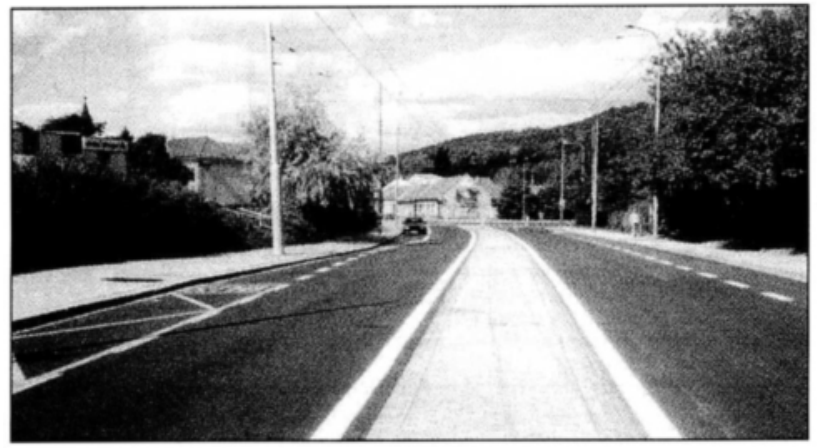

Fig 10. Middle traffic strip on a road
The minimal length of these sidewalk capes would be $5 \mathrm{~m}$. Columns on the sidewalk cape edge are fitted to locate and prevent illegal vehicle driving.

Green capes essentially improve the aesthetical design of communication, dislocate the homogeneity of its image and support the regulation of traffic flow speed. Their width would correspond to the parking lane width and their length is usually $2-4 \mathrm{~m}$. A mutual distance is recommended to offer up to 3-4 parking places between green capes (otherwise the effect of the green area would become extinct).

Local bottlenecks (Fig 12) stress the principal direction of pedestrians and cyclists across and over the intersection area and stress changes of a section's parameters. Therefore it is used only at isolated points and less often than sidewalk capes. A two-lane road width is usually $5,5 \mathrm{~m}$ wide and it is at least about $1 \mathrm{~m}$ narrower than the surrounding road. The length of a bottleneck reaches $10-15 \mathrm{~m}$ generally.

To ensure sufficient pedestrian safety it is necessary to provide a maximal speed limit of up to $50 \mathrm{~km} / \mathrm{h}$. Pedestrians maximally cross without stopping one-way traffic over one lane only. Therefore it is highly recommended to reduce the speed limit to $40 \mathrm{~km} / \mathrm{h}$ at pedestrian crossings in front of schools and offices.

The location of pedestrian crossings has to respect the real and main pedestrian flow directions. Crossings must be well arranged for all traffic participants (including areas on refuges - Fig 9) and sufficient stopping

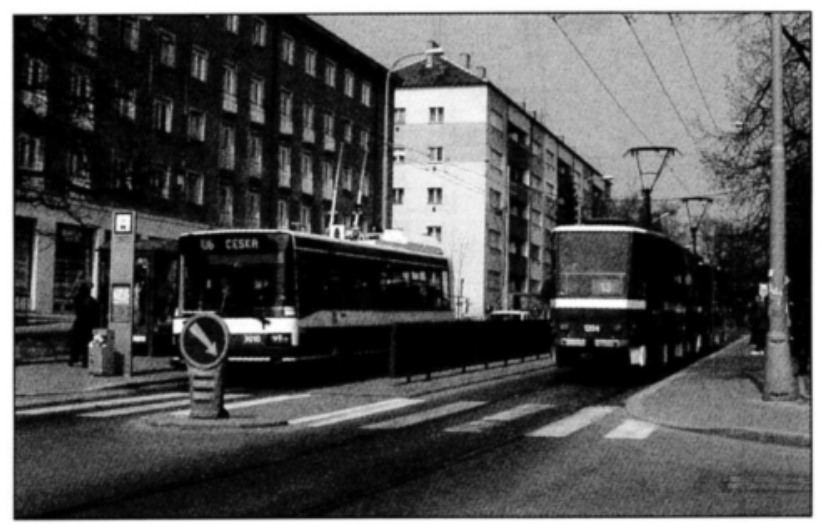

Fig 11. Sidewalk capes beside tram stops

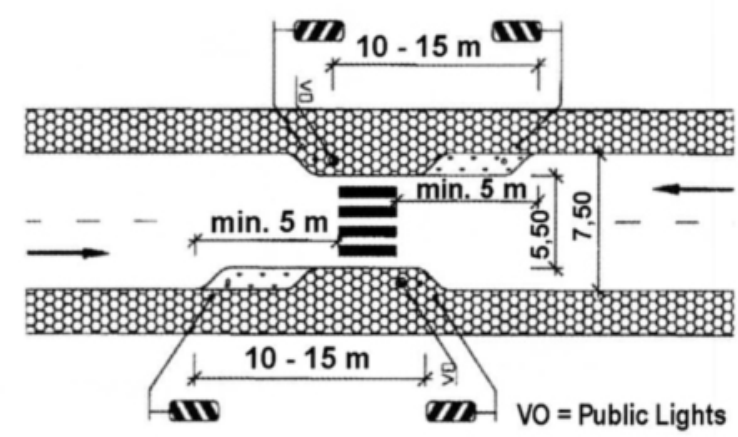

Fig 12. Local bottleneck of a traffic line 
places must be preserved. Pedestrians would be motivated towards the use of crossings by having traffic space layout, and with the help of the application of sidewalk capes (for example, Fig 3).

It is also possible to design pedestrian crossings in dense areas (100-200 $\mathrm{m}$ ) on through roads in towns/villages.

Small roundabouts are suitable for use at the entry into towns as well as in villages. Besides, many other well-known advantages (eg the reduction of traffic flow speed, improvement of traffic flow, reduction of accident frequency, advantageous option to crossroads with traffic lights ensuring the change over of sectors with different cross-sections) increase the aesthetic image of a town.

Changes of the types of pavements or colours at town/village entries as well as of through roads inside towns/villages contribute to the know-how and improvement of other traffic behaviour. This can be applied even in front of places requiring more attention and caution (eg pedestrian crossings, crossroads, traffic humps).

Road humps can be built in the shape of classical humps. Very short humps, also called road bumps, are not suitable on through roads in towns/villages or for a very significant speed reduction or in combination with pedestrian crossings. Road humps can use up the whole space of some intersections or traffic lanes along tram stops.

\section{Conclusions}

It is essential to modernise the existing roads in Lithuania in respect of levels in foreign countries. The purpose of the process of modern formation and traffic easing of through roads is to reach better safety levels for all participants of road traffic, the improvement of pedestrian and cyclist movement and conditions, optimisation of the used traffic space, to increase the aesthetic standard improvements of through roads and to slow down the environmental impact of air pollution and traffic noise.

General requirements and criteria for redesigning through roads are: to analyse the existing situation, to choose maximum speed limits along the whole road, to mark speed limits, to design traffic easing elements depending on their area of use. The main elements for designing traffic easing are optimisation of traffic line widths, resorting to new technology for drain edges, foresight of traffic islands according to purpose, layout or construction, the selection of middle traffic strips, sidewalk and green capes, pedestrian crossing, changing different pavement materials and their colours. A sustainable analysis of the traffic impact constitutes the conditions to modernise the existing through roads according to social, mobility, and environmental protection demands.

\section{References}

1. Graedel T. E.; Klee R. J. Getting serious about sustainability. Environmental Science \& Technology, Vol 36, No 4, 2002, p. 523-529.

2. Steponavičienè G.; Juškevičius P. Preconditions for sustainable city development. Town Planning and Architecture (Urbanistika ir architektūra), 2000, Vol XXIV, No 4, p. 137-140 (in Lithuanian).

3. Burinskienè $M$. Transport system development in towns. Ecological aspect. Environmental Engineering (Aplinkos inžinerija), 1995, Vol 3, No 1, p. 27-33 (in Lithuanian).

4. The principles of bypass planning and impact to city communication system in Vilnius (Vilniaus miesto aplinkkelių formavimo principai ir itaka miesto susisiekimo sistemai). Vilnius Plan, 2001. 50 p. (in Lithuanian).

5. Brown J.L. Out of the way. Journal of Civil Engineering, 2001, Vol 71, No 3, p. 60-65.

6. Burinskienè $M$. Analysis and prognosis of Vilnius urban street network. In: Civil engineering and environmental proceedings. Vilnius: Technika, 1998, p. 158-173 (in Lithuanian).

7. Juškevičius P. Planning of city communication systems (Miesto susisiekimo sistemu planavimas). Vilnius: Technika, 1995. 212 p. (in Lithuanian).

8. Strom S.; Nathan K. Site engineering for landscape architects. $3^{\text {rd }}$ edition. USA, Rutgers - The State University of New Jersey, 1997. 289 p.

9. Methodology for the design of through roads in built-up areas (Zasady pro navrhovani uprav prutahu silnic obcemi). Prague: Centrum dopravniho vyzkumu, 2001. 74 p. (in Czech).

10. Cyclist transport development in Czech Republic (Metodika rozvoj cyklisticke dopravy $v$ Ceske Republike). Prague: Transport Research centre, 2000. 65 p. (in Czech). 